\title{
用語知識ベースのための編集機能の試作
}

○渡辺基広、宮崎林太郎、後藤智範

神奈川大学 理学部

\section{Editing Function in Graphical Visualization for Lexical Knowledge \\ Base}

Motohiro WATANABE, Rintaro MTYAZAKI, Tomonori GOTOH

The two dimensional graphical browser for lexical knowledge base such as thesauri has been developed our laboratory. However browsing functions is not sufficient as tools for handling lexical data because the attributes of a term object and the structure between objects change.

The editing functions for lexical knowledge base with hierarchical structure has been developed. This paper describes the editing functions, and these examples of its usage. The problems of the functions and extended utilities are discussed.

\section{1.はじめに}

通常、シソーラス等のように用語間に狭義語や広義語の関倸がある用語木を編集する際に 編集者は、辞書データの入ったファイルを直接編集する方法が一般的である。しかしこの方 法は、データファイルにおいて編集対象となる用語についての用語情報や用語関係等の詳細 情報をあらかじめ調べておく必要がある。しかし、入力ミス等で編集が失敗した際、編集し た用語間の関係が崩れてしまう恐れがある。

当研究では、編集者が辞畫データを編集する際、用語情報をあらかじめ視覚的に表示して おき、その表示上で用語の編集を行なう機能を試作した。このことにより、利用者は用語間 の関係を視覚的に把握した上で用語木を編集することができ、編集後の用語関係をリアルタ イムに確認できることが実現した。

\section{2. 用語編集機能}

上記のような用語の編集機能を試作するにあたり、用語を視覚的に表すことのできるブラ ウザが必要である。当研究室では以前に作成した、Thesaurus Browser という用語木ブラウ ザの開発を行なってきた。そこで本報告では、当ブラウザに追加された編集機能について報 告する。

用語編集の流れとしては、編集対象となる用語に関する用語木を表示させ、この用語木中 
で編集対象の用語を選択する。その上で編集機能を選択するとその用語に対する編集 Window が表示され、それについての各種編集を行っていく。編集が確定されると、その編 集情報に基づき(データ構造としての)用語木を操作し、変更後の木構造を再表示させる。

用語木を編集する際に必要な機能として以下の機能が考えられる。

(1) 用語の追加

(2) 用語の削除

（3）用語の属性変更

(4) 用語(部分木)のコピー

（5）用語の詳細情報表示

これらの機能の詳細について以下に解説する。

\section{1 用語の追加}

この機能は、用語の狭義語として新規の用語を追加する時に用いる。編集機能で用語の追 加を選択し、追加する用語名を記入すると選択された用語の狭義語としてその用語が追加さ れる。図 1 において、左側は追加前、右側は、用語”new name”が追加された後の画面を示し ている。

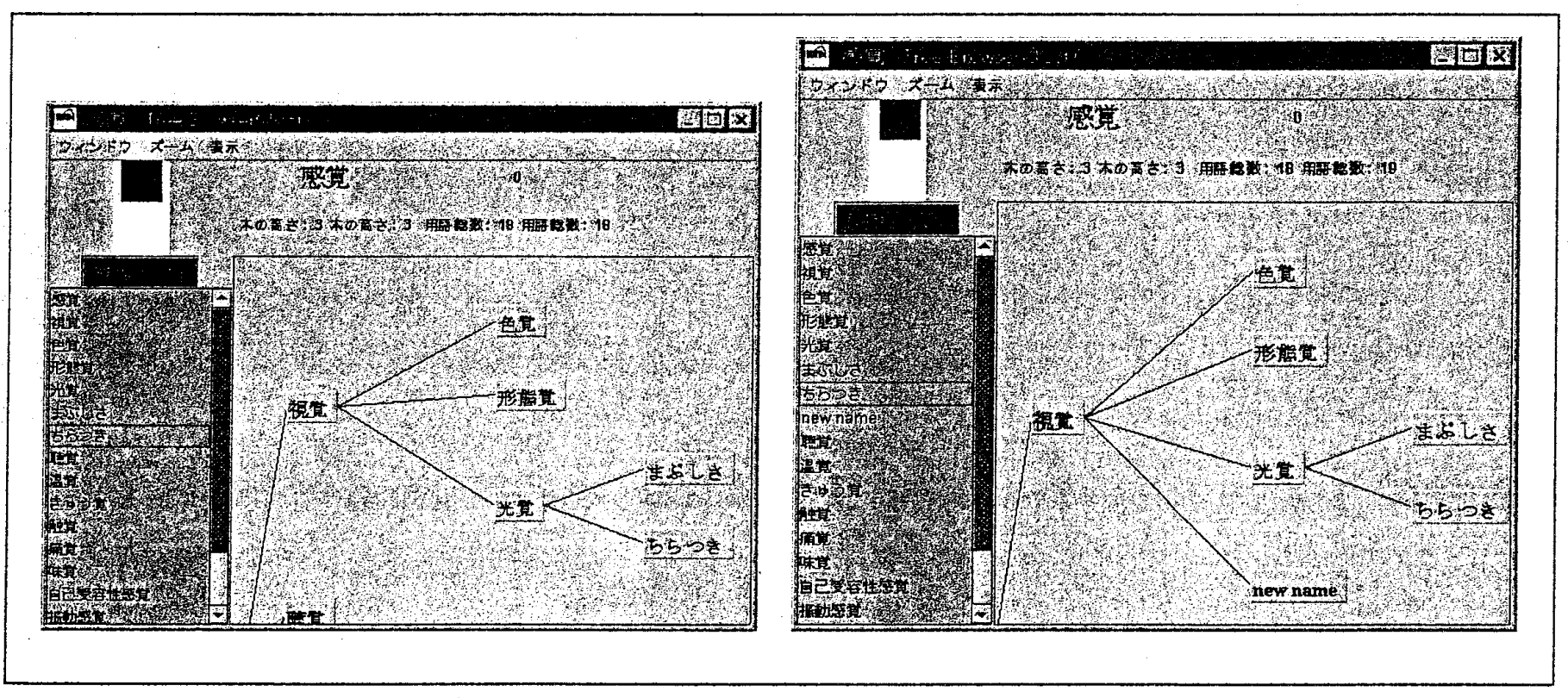

図 1 用語の追加例

\section{2 用語の削除}

この機能は、選択された用語を削除する機能であるが、その用語だけを削除するだけでは なく、その用語の下位用語の処理方法についても考える必要がある。以上のことを踏まえ、 今回提案する方法は以下の通りである。

（1）選択した用語以下の部分木の削除

（2）選択した用語のみを削除し、その用語の狭義語のどれかと入れ替える

（3）選択した用語のみを削除する

図 $2-1$ は削除操作の選択画面を示し、図 $2-2$ は(2)の操作を選択し、左側が削除前、右側が下位語 
「形感覚」と入れ替えられた状態を示している。

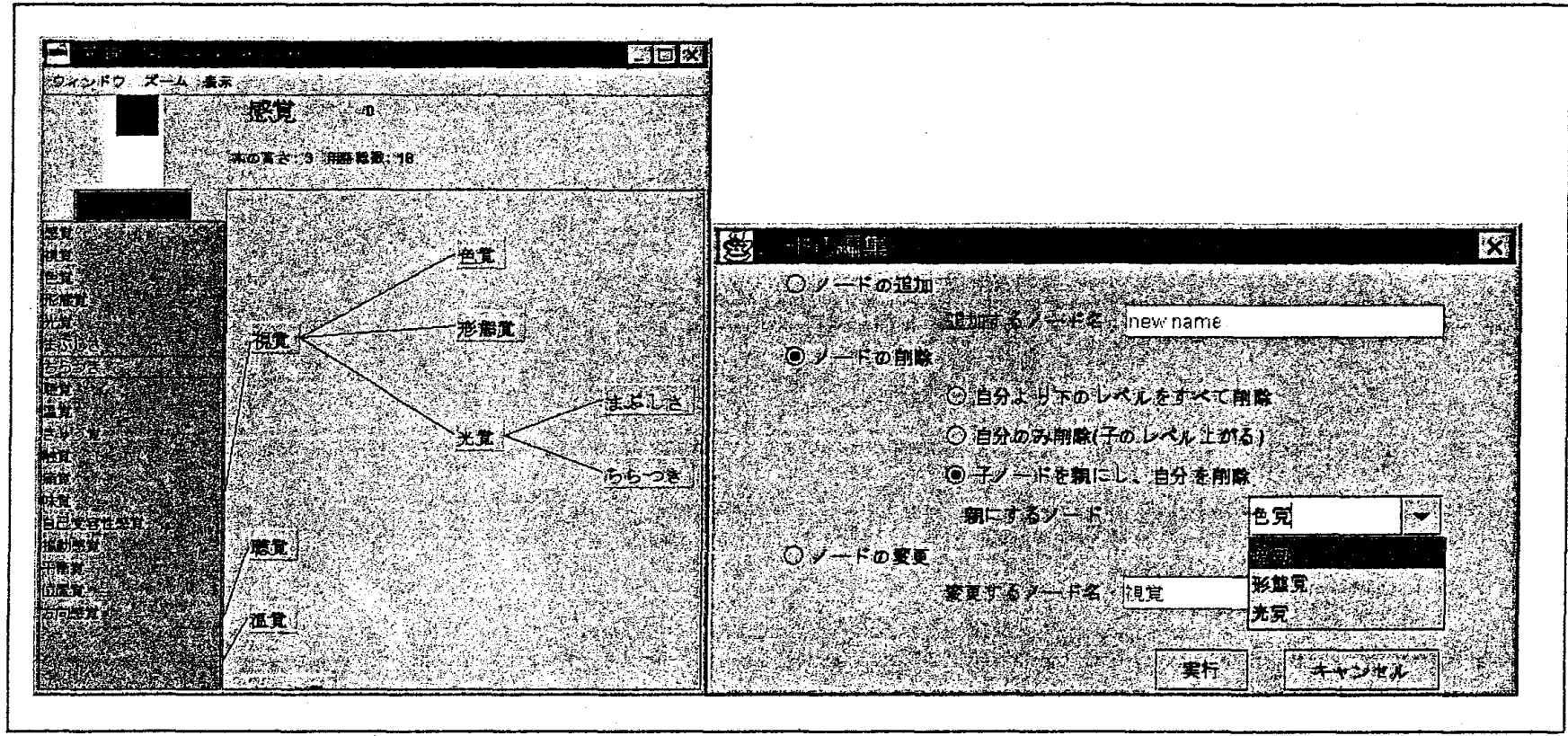

図 2-1 削除操作の選択画面

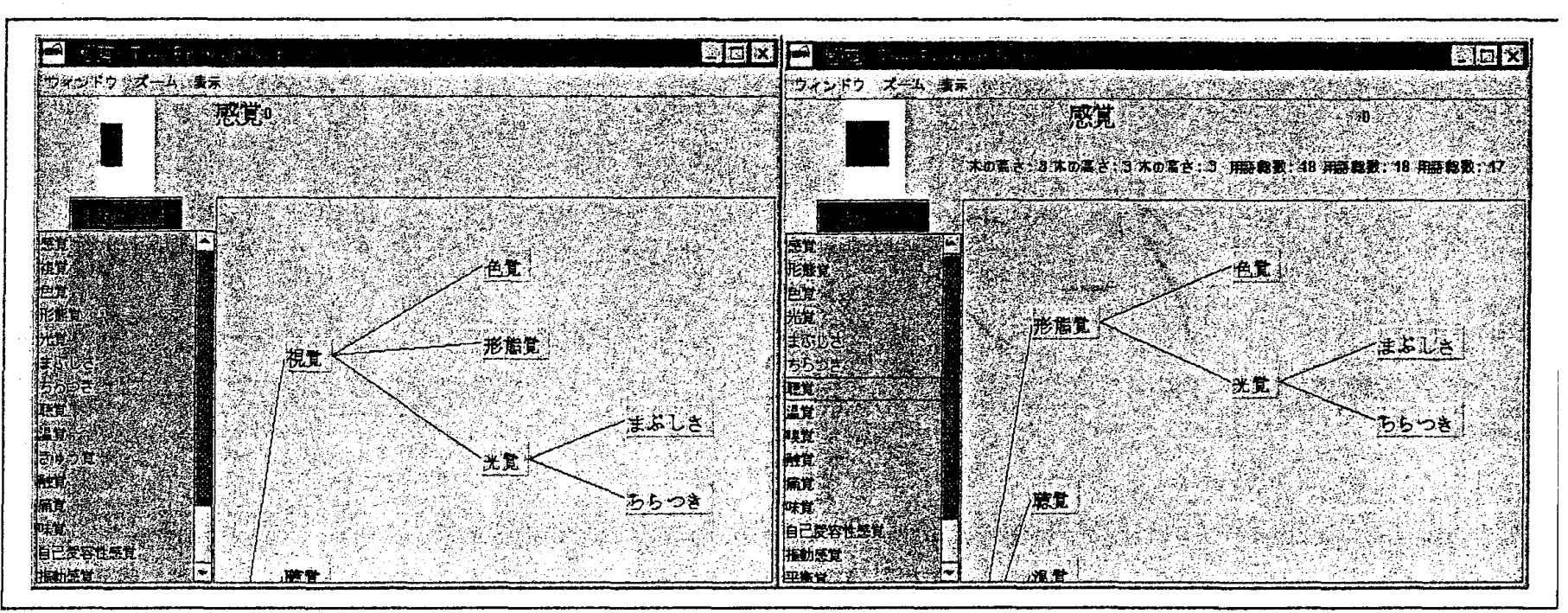

図 $2 \cdot 2$ 用語削除の例

\section{3 見出しの語の変更}

この機能は用語名などを変更する際に使用する機能であり、編集対象となる用語名を変更 するときに用いる。図 3 ここ操作例を示す。

\section{4 用語属性の詳細表示・変更}

用語木上では、そのノードの見出し語とその上下関保しか表示されていないため、その他 のデータ(レコード番号・用語の読み・木番号など)の詳細な情報を参照することができない。 用語の関係のみが記されているデータであればよいが、EDR 概念辞書のように、見出し語が 同じでも概念が異なるようなもの、また概念見出しのないような概念をブラウザで表現する 
際に、用語の説明がないと用語木の表示・編集が不便になる。このような辞書を用語木上で 表示するために、用語の詳細を表示する機能を追加することにより、用語情報を参照するこ とが可能になった。

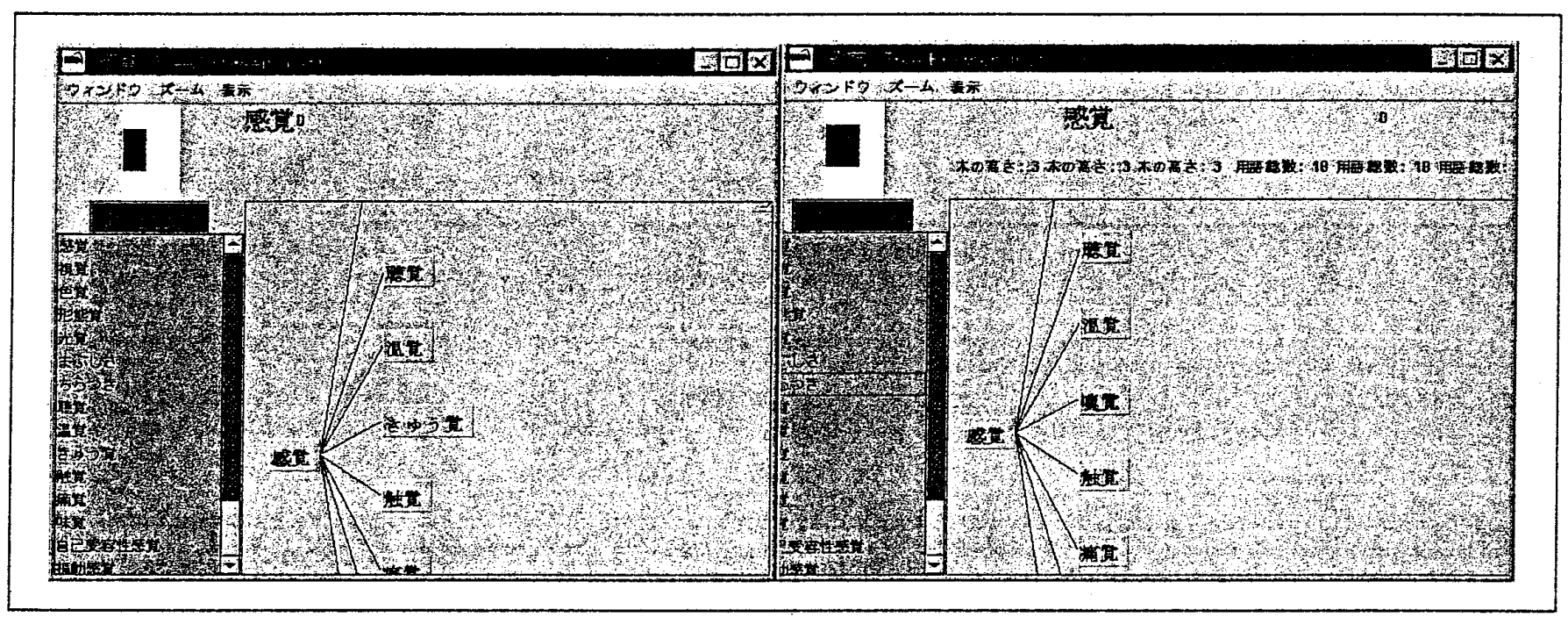

図 3 見出し語の変更例

\section{5 用語 (部分木)のコピー}

指定した用語以下の部分木のコピー・貼り付け機能をも実装した。この機能により、ある用語 の下位に他の用語以下の部分木をコピーすることができる。

\section{3. 考察}

上記の編集機能は、既存の木、部分木の編集に対して有効である。全く新規に木構造を生 成する、あるいは木構造生成の対象となる用語りストのみが存在するような状況では、上記 の機能では木の構築はその操作性において不十分と考えられる。木構造の生成は、用語の上 位／下位用語を追加することであるが、これを 1 つ つ行うのではなく、1回の操作で複数 の用語を下位語化するような機能も必要であるう。

また、異なった属性群をもつ複数の用語木間での編集では、木構造以外の属性をどのよう にするか、という問題が生ずる。このようなてどん編集状況に対処するためには、用語知識 ベースの XML データベース化が有効であると思われる。

\section{4. おわりに}

当研究室では、数年来用語知識ベースの操作ツールを開発・実装している。今回の報告で は、従来の二次元視覚化表示に加え、同様の視覚化、操作感覚での編集機能を開発した。今 後は、考察で指摘した問題の解決手段、さらにEDR 電子化辞畫やNTTの日本語語彙体系の ような意味関係で結合されたグラフ構造データの表示、編集機能を開発する予定である。 